\title{
3 Research Square

\section{Increased Proportion of TH17, TH22 and TC22 Cells and Correlations to IL-22, IL-10 and Clinical Parameters in a Cohort of Patients With Ankylosing Spondylitis From Northern Sweden.}

Kristina Lejon ( $\nabla$ kristina.lejon@umu.se )

Umea University: Umea Universitet https://orcid.org/0000-0001-5025-6539

Urban Hellman

Umeå University, Department of Public Health and Clinical Medicine

Lan Do

Umeå University, Department of Public Health and Clinical Medicine

Anjani Kumar

Umeå University, Department of Pulic Health and Clinical Medicine

Helena Forsblad d'Elia

Umeå University, Department of Public Health Health and Clinical Medicine

\section{Research article}

Keywords: Radiographic axial spondyloarthritis, Ankylosing spondylitis, TH17, TH22, TC22

Posted Date: January 14th, 2021

DOI: https://doi.org/10.21203/rs.3.rs-144140/v1

License: (c) (i) This work is licensed under a Creative Commons Attribution 4.0 International License.

Read Full License 


\section{Abstract}

\section{Background}

Increased levels of TH17 and TH22 as well as TC17 and TC22 cells and their related cytokines have previously been associated with ankylosing spondylitis (AS). However, the status of these inflammatory cells in a well characterized AS cohort from northern Sweden has not been studied.

\section{Objectives}

The aim of this study was to confirm the increased presence of inflammatory $T$ cell subsets in peripheral blood of patients with AS and controls from northern Sweden and explore the association with clinically relevant parameters with the level of the inflammatory T cell subset(s) and related cytokines.

\section{Methods}

Peripheral blood mononuclear cells (PBMCs) from a cohort of 50 patients (66\% men) with AS from Region Västerbotten (age 52.1 \pm 9.0 years, $100 \%$ HLA-B27+) and 50 pairwise sex- and age-matched blood donor controls (66\% men, mean age $54.6 \pm 9.1$ years) were stained for CD45, CD3, CD4, CD8, intracellular IL-17 and IL-22 and analyzed by flow cytometry. In addition, levels of IL-17, IL-22 and IL-10 in plasma were determined. The patients with AS were assessed for mSASSS, hsCRP, ESR, BASMI, BASFI, ASDAShsCRP and BASDAl.

\section{Results}

Pairwise comparisons of AS patients and controls showed a 1,5x to 2-fold increase of TH17, TH22 and TC22 cells among CD45+CD3+ lymphocytes in PBMCs in male patients $(p=0.013, p=0.003$ and $p=0.024$ respectively). Levels of IL-22 in plasma and proportion of TC17 correlated in male patients $\left(R_{s}=0.499\right.$ $p=0.003)$ and plasma levels of IL-10 showed an inverse correlation to TC17 in all patients $\left(R_{s}=-0.276\right.$ $p=0.05$ ). In addition, male patients with $\geq 1$ syndesmophyte showed significantly higher proportion of TH17 cells $(p=0.038)$. In female AS patients there was a negative correlation between TC22 and hsCRP $\left(R_{s}=-0.573, p=0.016\right)$.

\section{Conclusions}

We confirm an increased proportion of TH17, TH22 and TC22 cells in blood in AS male patients from northern Sweden. A positive correlation with the proinflammatory cytokine IL-22 and reverse correlation of the anti-inflammatory cytokine IL-10 in relation to TC17 corroborate the influence of these cells. In addition, a role of $\mathrm{TH} 17$ in the pathogenesis process is supported by the correlation between $\mathrm{TH} 17$ proportions and the presence of $\geq 1$ syndesmophyte.

\section{Background}


Ankylosing spondylitis (AS) also referred to as radiographic axial spondyloarthritis ( $\mathrm{r}$-axSpA) belongs to the cluster of SpA diseases. AS is characterized by typical radiographic alterations in the sacroiliac joints due to sacroiliitis and often also with typical skeletal changes in the spine caused by the inflammatory process [1]. For unknown reason AS is more common in men compared with women and men also develop, at a group level, more severe disease with more spinal radiographic alterations as well as a higher proportion of extra-articular manifestations (EAM) [2]. Genetic association with HLA-B27 is found in about $85-90 \%$ of the AS patients [3, 4]. However, the pathogenic underlying mechanisms in AS remain to befully revealed. Altered function in antigen presenting cells has been suggested where HLA-B27, with its tendency to misfold and dimerize, may trigger the interleukin-23/interleukin-17 (IL-23/IL-17) pathway [5-9].

Involvement of non-lymphoid IL-17 expressing cells [10] as well as a relative increase in the proportion of inflammatory T cell subsets such as TH17, TH22, TC17 and TC22 in AS patients [11-13] has previously been demonstrated, where the effect of the increased cytokines, including IL-17, IL-22 and IL-23 [14, 15], has been linked to bone remodeling [16-19]. In addition, treatment with anti-IL-17A antibodies has also proven clinically beneficial further supporting the involvement of the IL-17/IL-23 pathway in the pathogenesis process [20]. However, association between increased levels of particular T cell subsets and clinical parameters is still to be demonstrated [21]. Moreover, the influence of sex hormones in relation to inflammatory cellular subsets as well as clinical parameters has also been sparsely investigated [22] with increased levels of IL-17 and TH17 cells in AS males but no significant differences observed for AS females in the same investigation [23].

In this study we aimed to test the hypothesis that particular inflammatory T cell subsets are increased in AS patients and associate with clinical characteristics of disease severity and some pro- and antiinflammatory cytokines in a cohort of well phenotyped AS patients from northern Sweden.

\section{Materials And Methods}

\section{Patient cohort}

One-hundred and fifty-five patients with ankylosing spondylitis (AS) that fulfilled the modified New York criteria for AS [24] were included in the Backbone study in northern Sweden, investigating severity and comorbidities in AS. The mean age of the AS patents in Backbone was $55.5 \pm 11.4$ years and 107 (69.0\%) was men. The patients with AS underwent clinical examination and answered questionnaires regarding medication and disease-related data. Mobility was measured by the Bath Ankylosing Spondylitis Metrology Index (BASMI). Disease activity and physical function were assessed using the Bath Ankylosing Spondylitis Disease Activity Index (BASDAI), the Ankylosing Spondylitis Disease Activity Score based on C-reactive protein (ASDAS-CRP) and the Bath Ankylosing Spondylitis Function Index (BASFI) [25]. Spinal radiographic alterations were graded according to the modified Stoke Ankylosing Spondylitis Spinal Score (mSASSS) [26]. The overall scoring scale ranges from 0 to 72, with 72 representing complete ankyloses. An mSASSS score $\geq 2$ at a vertebral corner was considered as having a syndesmophyte. 
Blood samples were drawn in the morning after overnight fasting and erythrocyte sedimentation rate (ESR), high sensitivity C-reactive protein (hsCRP) were analyzed consecutively. HLA-B27 were analyzed using standard laboratory techniques. Plasma was stored and frozen in $-80^{\circ} \mathrm{C}$. Plasma levels of IL-17A, IL-22 and IL-10 were measured on the Meso Scale Discovery U-PLEX platform according to the manufactory instructions (Meso Scale Discovery ${ }^{\circledR}$, Rockville, USA). According to the manufacturer the lower level of detection (LLOD) for IL-17A was $2.6 \mathrm{pg} / \mathrm{mL}$, for IL-22 $0.13 \mathrm{pg} / \mathrm{mL}$ and for IL-10 $0.14 \mathrm{pg} / \mathrm{mL}$. IL-17A was below the LLOD in $90 \%$ of the patients and is not further presented.

At inclusion in Backbone, 106 (68.4\%) patients donated samples for storing and freezing PBMCs in $-80^{\circ} \mathrm{C}$ according to the protocol described below. Based on results from previous studies [21] a sample size of 50 patients and controls was calculated to be sufficient for this project (i.e. power $80 \%$ ). The control group consisted of blood donors fulfilling the Swedish criteria for blood donation [27].The upper age limit for blood donors was 65 years and thus AS patients $>65$ years of age were excluded, leaving 81 remaining patients. We also excluded HLA-B27 negative patients $(n=3)$ resulting in 78 patients. In order to keep similar sex-distribution as in Backbone nineteen men and nine women were further excluded, evenly distributed according to age. Finally, 50 patients with AS, mean age $52.1 \pm 9.0$ years, $33 / 50,66 \%$ men and $17 / 50,34 \%$ women and 50 blood donor controls matched on age (mean age $54.6 \pm 9.1$ years) and sex $(33 / 50,66 \%$ men, $17 / 50,34 \%$ women) were included in this study. No significant difference in age $(p=0.1)$ or sex $(p=1)$ was found between cases and controls. PBMCs from the controls were handled according to the same protocol as the AS patients. The study was approved by the Ethics Review Board at Umeå University, Umeå, Sweden (Dnr 2016/208-31, Forsblad-d'Elia, PI), and carried out in accordance with the Helsinki declaration. Written consent was obtained from all the participants.

\section{Sample collection and freezing}

Blood from AS patients and controls was collected in cell preparation tubes, BD Vacutainer ${ }^{\circledR}$ CPTTM (Becton Dickinson, NJ, USA). The tubes were centrifuged for $15 \mathrm{~min}$ at $1500 \mathrm{xg}$ and $50 \%$ of the plasma was removed, followed by mixing of buffy coat and remaining plasma. The cell suspension was transferred to a $50 \mathrm{~mL}$ tube and kept on ice. Roswell Park Memorial Institute (RPMI) -1640 medium (Gibco, Thermo Fisher Scientific, USA)) was added to a total volume of $40 \mathrm{~mL}$. Cell viability and concentration were assessed. The cell suspension was then centrifuged at $250 \mathrm{xg}$ for $10 \mathrm{~min}$ followed by removal of supernatant. The cell pellet was resuspended in fetal bovine serum (FBS) to a concentration of $10 \times 10^{6}$ cells/mL FBS. Freeze medium ( $90 \% \mathrm{FBS} / 10 \% \mathrm{DMSO}$ ) was carefully added, drop by drop, in the same amount as FBS. Cell samples were stored at $-80^{\circ} \mathrm{C}$.

\section{Flow cytometry}

Frozen cells were thawed lightly in $37^{\circ} \mathrm{C}$, put in ice-cold $\mathrm{Gibco}^{\mathrm{TM}} \mathrm{PBS} 1 \times \mathrm{pH} 7.4$ (Thermo Fisher scientific, Waltham, MA, USA), and centrifuged at $300 \mathrm{xg}$ for $10 \mathrm{~min}$ in $4^{\circ} \mathrm{C}$. Cells were washed in PBS and 0.5-2 $\mathrm{x}$ $10^{6}$ cells weretransferred to tubes and stimulated $5 \mathrm{~h}$ in $37^{\circ} \mathrm{C}$ in an $5 \% \mathrm{CO}_{2}$ incubator in RPMI-1640, Iglutamine, PenStrep (Gibco, Thermo Fisher scientific, Waltham, MA, USA )with PMA 50ng/ml, 
lonomycin (both from Sigma-Aldrich, Saint Louis, MO, USA) $1 \mu \mathrm{g} / \mathrm{ml}$ ) in the presence of Golgiplug (diluted 1/1000) (BD Biosciences). After a PBS wash, cells were stained in BD Horizon ${ }^{\text {TM }}$ Fixable Viability Stain 510 according to manufacturer's instruction. After washing with FACS buffer (Gibco ${ }^{\text {TM }}$ PBS $1 \times 1 \times$ pH 7.4 containing $3 \%$ Gibco $^{\text {TM }}$ FBS (Thermo Fisher scientific) and $0.01 \%$ sodium azide (Sigma-Aldrich)), Brilliant Stain Buffer (BD Biosciences, San Jose, CA, USA) and surface stained with a mix of the following antibodies (all from BD Biosciencesunless otherwise noted): anti-CD4 (RPA-T4, BV605), anti-CD3 (APA1/1, FITC), anti-CD8 (SK1, APC-H7) and intracellularly stained using BD Perm/Wash ${ }^{\text {TM }}$, anti-IL-17A (SCPL1362, PE), anti-IL-22 (IL22JOP, APC) (eBioscience ${ }^{\mathrm{TM}}$ ) according to manufacturer's instruction.

Stained samples were resuspended in FACS buffer andanalyzed in an LSRII FACS machine (BD Biosciences). Data was analyzed using FACSDiva Software (BD Biosciences) or FlowJo v10.4.2 (FlowJo, LLC, Ashland, OR, USA) software. In the analysis doublet discrimination were applied, i.e. events in the flow cytometry that potentially could be the result of cells appearing in pairs and not as single cells were excluded from the analysis. Gates were set using fluorescent minus one (FMO) controls or on discrete populations.

\section{Statistical method}

Descriptive statistics are presented as median with interquartile range (IQR) or absolute number with percentages. Wilcoxon signed ranks samples test with paired samples was applied when comparing cases and controls and when comparing groups with AS, Mann-Whitney $U$ test was used for continuous variables. Correlation analysis was performed using Spearman's rank correlation test. All tests were twotailed and $p \leq 0.05$ was considered statistically significant. All data were analyzed using IBM SPSS Statistics 25 (IBM, Armonk, NY, USA).

\section{Results}

\section{Characteristics of the AS cohort}

Fifty AS patients and fifty matched controls (blood donors) were included in the study. Characteristics of the AS patients are displayed in Table 1. The men with AS had significantly higher mSASSS and more often $\geq 1$ syndesmophyte compared with the women otherwise characteristics did not differ significantly.

\section{Increased frequency of TH17, TH22 and TC22 cells in male AS patients and correlations to cytokines and clinical parameters}

To reveal the potential contribution of inflammatory T-cell subsets in our AS cohort flow cytometry analyses of peripheral blood was undertaken. Intracellular staining of IL-17 and IL-22 together with expression of CD 4 and CD 8 were used to discriminate TH17, TH22, TC17 and TC22, respectively. The full gating strategy is shown in Figure 1.

The proportion of IL-17 and IL-22 expressing cells was generally sparse, but consistently detectable by flow cytometry. Paired analysis showed a significantly higher proportion of TH17 cells ( $p=0.005), \mathrm{TH} 22$ 
cells $(p=0.008)$ and TC22 cells $(p=0.025)$ in AS patients compared to controls. Next, we split the groups in females and males. In figure 2 the observed distribution in respective group is displayed in truncated violin plots. Group wise comparison revealed a statistically significant increased proportion of $\mathrm{TH} 17$ cells (0,34\%, IQR $0,18-0,86 \%$ vs. $0,16 \%$, IQR $0,06-0,37 \%, p=0.013)$, TH22 cells $(0,25 \%$, IQR $0,15-0,59 \%$ vs. $0,14 \%$, IQR $0,05-0,30 \%, p=0.003)$ and TC22 cells $(0,07 \%$, IQR $0,04-0,13 \%$ vs. $0,06 \%$, IQR $0,02-0,10 \%, p=0.024)$ in the male group compared to controls (Figure 2). In the female group no significant difference was observed, although a similar trend in increased median for all three T cell subsets in the AS female group was noted. Additional flow cytometry analysis including NK cells (CD3-CD19-CD14-CD16+CD56+/-) and MAIT cells (CD3+CD4-CD8+/-CD161 ${ }^{\text {high }}$ va7. $2^{+}$) that previously been shown to be altered in AS patients, failed to demonstrate any difference in the proportion of cells, comparing AS patients and controls overall and divided by sex (data not shown).

Cytokine levels in the plasma, i.e. IL-10 and IL-22 have previously been correlated to the presence of particular T cell subsets. Although we did not detect any difference in the proportion of TC17 comparing AS patients and controls a correlation between levels of TC17 and IL-22 was detected $\left(R_{s}=0.283\right.$, $p=0.046)$, that was explained by the male AS patients $\left(R_{s}=0.499, p=0.003\right)$. Moreover, a reverse correlation between TC17 and the level of IL-10 was also observed in the whole group $\left(R_{s}=-0.276, p=0.05\right)$ and in the male AS patients also TH17 correlated negatively with plasma levels of IL-10 $\left(R_{S}=-0.374, p=0.035\right)$.

Next we analyzed the correlation between clinical parameters and the different $T$ cell subsets. A correlation between TH17 and syndesmophyte $\left(R_{s}=0.304, p=0.032\right)$ was observed and this was explained by the male patients $\left(R_{s}=0.367, p=0.036\right.$, females n.s.). Male patients with $\geq 1$ syndesmophyte $(n=19)$ showed significantly higher proportion of $\mathrm{TH} 17$ cells compared with males without syndemophytes $(\mathrm{n}=14)(0.46 \%(0.26-1.28)$ vs. 0,19\% (1.14-0.40), $p=0.038)$. Furthermore, an inverse correlation between BMI and TC22 was noted $\left(R_{S}=-0.286, p=0.044\right)$ explained by the male patients $\left(R_{S}=-0.430, p=0.012\right)$.

\section{Clinical parameters associate differently to T cell subsets and cytokines comparing pre-versus postmenopausal AS female patients}

Analysis of all female AS patients showed that the level of hsCRP correlated negatively with TC22 $\left(R_{S}=-0.573, p=0.016\right)$ and also smoking ever correlated negatively to TC22 $\left(R_{S}=-0.586, p=0.013\right)$. Female patients who were smokers/had been smokers displayed significantly lower proportion of TC22 compared with female patients who had never been smokers $(0.020 \%(0.00-0.035)$ vs. $0,098 \%(0.028-$ $0.25), p=0.019)$. As the group of female AS patients included women with an age span of 38.5-63 years we split the group according to menopausal status. Characteristics for the two subgroups are shown in Table 2. Reanalysis of the correlation of TC22 and hsCRP revealed that this was mainly explained by the postmenopausal group $\left(R_{s}=-0.635, p=0.036, n=11\right)$. Further analysis of these two subgroups in relation to the $T$ cell subsets revealed a strong reverse correlation between TC17 and IL-10 $\left(R_{s}=-0.688, p=0.019\right)$ in the postmenopausal females and a correlation between TC22 and BASFI $\left(R_{s}=0,930, p<0,008\right)$ in premenopausal females $(n=6)$. 


\section{Discussion}

Involvement of inflammatory related, i.e. IL-17 and IL-22 producing lymphoid cells in the pathogenesis of AS has been proposed, and increased proportion of TH17 have been found in blood of AS patients [1113]. Our analyses of well characterized AS patients from northern Sweden are in line with these previous findings. Thus, in male AS patients a significant increase of TH17 was observed. A similar trend for increased levels of TH17 cells, although not significant, was observed in female AS patients. In our material, we were unable to correlate TH17 and IL-17 levels, as IL-17 unfortunately was below the detection limit in the majority of the patients. However, a correlation between TH17 and corresponding increased IL-17 levels has been shown previously $[14,15]$. TH17 cells can produce IL-17 and to some extent IL-22, which is in contrast to the $\mathrm{TH} 22$ subset that has been demonstrated to exclusively produce IL-22 [28-30]. A pathogenic role of TH22 and TC22 in inflammatory diseases including AS and psoriasis has been suggested [21, 31, 32], and IL-22 has convincingly been associated to autoimmune disease [33]. Thus, in our cohort, male AS patients displayed a significant increase of both TH22 and TC22 cells. In addition, we detected a correlation between the level of TC17 and IL-22 levels, that either could be a direct association, i.e. increased levels of IL-22 producing TC17 cells, or an indirect association as this cytokine is produced by several cell types and the intricate cross regulation occurring.

Regulation of differentiation and effector functions of the above-mentioned inflammatory cells is promoted by several cytokines, i.e. IL-23, as well as IL-1 $\beta$, IL-6, IL-21 [34]. The cytokine IL-10, on the contrary has been shown to down-regulate inflammation by inducing TH17 cells to differentiate to IL-10 producing Tregs $[35,36]$. In addition, the microbiota seems to play a role in this situation. We and others have previously found signs of an altered micobiota in patients with AS [37, 38]. In our analysis we also detected reverse correlation between IL-10 and TC17, implicating a similar cross-regulation of TC17 as has been observed for TH17. In addition an inverse correlation between TH22 and IL-10, and the development of Tregs has also been shown, including immune responses in the gut, emphasizing the intricate crosstalk between all these subsets with the environment [39].

Microbial dysbiosis as one key initiating factor in AS, including IL-23 production by gut epithelial cells has been proposed to contribute to $\mathrm{TH} 17$ and TH22 differentiation and dysfunctional IL-10 mediated regulation. In addition, the strong HLA-B27 contribution in AS development has recently been attributed to protein misfolding in antigen producing cells leading to autophagy and subsequent IL-23 production [40]. The fact that two potential independent molecular causes could promote the same disease related mechanism, i.e. Type 3 immunity, is in line with the multifactorial nature of AS [34]. It is interesting to speculate that the increase of anti-CD74 antibodies in AS patients observed by both us [41] and others $[42,43]$ could indeed also be due to defective antigen processing and exposure of CD74 (i.e. li - the invariant chain) in a non-appropriate manner.

In this study we found an association between $\mathrm{TH} 17$ levels and the presence of syndesmophyte in male patients. This is to our knowledge the first study that can correlate clinical parameters with increased $\mathrm{TH} 17$, corroborating the role of $\mathrm{TH} 17$ in the pathogenesis of AS. We reason that as the female group was 
so smaller in size, together with the fact that very few within the group $(n=4)$ displayed syndesmophytes, makes the power too low to be able to detect this in this group. Interestingly however, the female AS group displayed a strong correlation between the TC22 subset and BASFI in the pre-menopausal group. As this was not found in the male AS patients nor for the female post-menopausal AS patients we speculate that female sex hormones influence this trait. The role of sex hormones influencing AS disease activity is further corroborated by the fact that a correlation between TC22 and BASFI was only observed in pre-menopausal females. This emphasize the importance to take this factor in account studying AS initiation and progression.

Lastly, BMI has been suggested to influence AS disease activity and progression of AS related radiographic spinal alterations both by a mechanical as well as an adipose related inflammation $[2,44$, 45]. In our study we found that this life style factor, as well as smoking ever and hsCRP, that also have been shown to correlate with AS, actually correlated negatively to the level of TC22 cells. Further studies, including $T$ cell subset dynamics in relation to life style factors could shed light on the underlying mechanisms.

The pathogenesis of AS is multifactorial and involves altered immune reactions as well as nonimmunological factors. Thus, the contribution of inflammatory $T$ cells in this process, as we have shown in the current study, should be noted as one piece in this complex puzzle.

\section{Conclusion}

In our study we found a significantly increased proportion of TH17, TH22 and TC22 cells in blood in male AS patients from Northern Sweden. A positive correlation with the proinflammatory cytokine IL-22 and reverse correlation of the anti-inflammatory cytokine IL-10 in relation to TC17 corroborate the influence of these cells in the disease process. Lastly, the fact that male AS patients with $\geq 1$ syndesmophyte display an increased proportion of TH17 suggest a possible direct link between this inflammatory $\mathrm{T}$ cell subset and the pathogenesis process in AS.

\section{Abbreviations}

AS Ankylosing spondylitis

BASDAI Bath Ankylosing Spondylitis Disease Activity Index

BASFI Bath Ankylosing Spondylitis Functional Index

BASMI Bath Ankylosing Spondylitis Metrology Index

hsCRP C-reactive protein (high sensitivity)

cs/bDMARDs Conventional synthetic or biologic disease modifying anti-rheumatic drugs 
DMARD Disease modifying anti-rheumatic drug

ELISA Enzyme-linked immunosorbent assay

ESR Erythrocyte sedimentation rate

IL Interleukin

r-axSpA radiographic axial spondyloarthritis

NSAID Non-steroidal anti-inflammatory drug

\section{Declarations}

\section{Ethical Approval and Consent to participate}

The study was approved by the Ethics Review Board at Umeå University, Umeå, Sweden (Dnr 2016/20831, Forsblad-d'Elia, PI), and carried out in accordance with the Helsinki declaration. Written consent was obtained from all the participants.

Consent for publication: All authors approved the final version.

Availability of supporting data and materials: The data sets analyzed during the current study are not publicly available due to the Swedish legislation (the Personal Data Act), but a limited and fully anonymized data set that support the main analyses is available from the corresponding author on request.

Competing interests: The authors declare no conflicts of interest.

Funding: This work was supported by Umeå University, The Swedish Research Council [2016-02035], the County of Västerbotten [ALFVLL-640251], King Gustaf Vth 80-year Foundation [FAl-2017-0454], Västerbotten's Association Against Rheumatism, The Swedish Association Against Rheumatism, The Norrland's Heart Foundation and Mats Kleberg's Foundation.

Authors' contributions: Study design was performed by KL, UH and HFdE. Sample and patient related data collection was done by AK and HFD. Laboratory work and data collection was performed by $\mathrm{KL}, \mathrm{UH}$, $\mathrm{LD}$ and AK. Data analysis was performed by KL, UH and HFdE. Interpretation of data and writing of the manuscript was done by KL, UH and HFdE.

Acknowledgements: We wish to thank the research nurses at the University Hospital of Umeå, Viktoria von Zweigbergk and Jeanette Beckman Rehnman, for assisting with the project. We also want to acknowledge all participants in the study.

\section{Authors' information:}


Kristina Lejon: kristina.lejon@umu.se

Urban Hellman: urban.hellman@umu.se

Lan Do: lan.do@umu.se

Anjani Kumar: anjanibhu@gmail.com

Helena Forsblad-d’Elia: helena.forsblad.delia@umu.se

\section{References}

1. Braun J, Sieper J: Ankylosing spondylitis. Lancet 2007, 369(9570):1379-1390. https://doi.org/10.1016/S0140-6736(07)60635-7.

2. Deminger A, Klingberg E, Geijer M, Gothlin J, Hedberg M, Rehnberg E, Carlsten H, Jacobsson LT, Forsblad-d'Elia H: A five-year prospective study of spinal radiographic progression and its predictors in men and women with ankylosing spondylitis. Arthritis Res Ther 2018, 20(1):162. https://doi.org/10.1186/s13075-018-1665-1.

3. Brewerton DA, Hart FD, Nicholls A, Caffrey M, James DC, Sturrock RD: Ankylosing spondylitis and HLA 27. Lancet 1973, 1(7809):904-907. https://doi.org/10.1016/s0140-6736(73)91360-3.

4. Bowness P: Hla-B27. Annu Rev Immunol 2015, 33:29-48. https://doi.org/10.1146/annurev-immunol032414-112110.

5. Taurog JD, Chhabra A, Colbert RA: Ankylosing Spondylitis and Axial Spondyloarthritis. N Eng/ J Med 2016, 374(26):2563-2574. https://doi.org/10.1056/NEJMra1406182.

6. DeLay ML, Turner MJ, Klenk El, Smith JA, Sowders DP, Colbert RA: HLA-B27 misfolding and the unfolded protein response augment interleukin-23 production and are associated with Th17 activation in transgenic rats. Arthritis Rheum 2009, 60(9):2633-2643. https://doi.org/10.1002/art.24763.

7. Bowness P, Ridley A, Shaw J, Chan AT, Wong-Baeza I, Fleming M, Cummings F, McMichael A, Kollnberger S: Th17 cells expressing KIR3DL2+ and responsive to HLA-B27 homodimers are increased in ankylosing spondylitis. J Immunol 2011, 186(4):2672-2680. https://doi.org/10.4049/jimmunol.1002653.

8. Loll B, Fabian H, Huser H, Hee CS, Ziegler A, Uchanska-Ziegler B, Ziegler A: Increased Conformational Flexibility of HLA-B*27 Subtypes Associated With Ankylosing Spondylitis. Arthritis Rheumatol 2016, 68(5):1172-1182. https://doi.org/10.1002/art.39567.

9. Colbert RA, DeLay ML, Layh-Schmitt G, Sowders DP: HLA-B27 misfolding and spondyloarthropathies. Prion 2009, 3(1):15-26. https://doi.org/10.4161/pri.3.1.8072.

10. Appel H, Maier R, Wu P, Scheer R, Hempfing A, Kayser R, Thiel A, Radbruch A, Loddenkemper C, Sieper $\mathrm{J}$ : Analysis of IL-17(+) cells in facet joints of patients with spondyloarthritis suggests that the innate 
immune pathway might be of greater relevance than the Th17-mediated adaptive immune response. Arthritis Res Ther 2011, 13(3):R95. https://doi.org/10.1186/ar3370.

11. Shen H, Goodall JC, Hill Gaston JS: Frequency and phenotype of peripheral blood Th17 cells in ankylosing spondylitis and rheumatoid arthritis. Arthritis Rheum 2009, 60(6):1647-1656. https://doi.org/10.1002/art.24568.

12. Jandus C, Bioley G, Rivals JP, Dudler J, Speiser D, Romero P: Increased numbers of circulating polyfunctional Th17 memory cells in patients with seronegative spondylarthritides. Arthritis Rheum 2008, 58(8):2307-2317. https://doi.org/10.1002/art.23655.

13. Smith JA, Colbert RA: Review: The interleukin-23/interleukin-17 axis in spondyloarthritis pathogenesis: Th17 and beyond. Arthritis Rheumatol 2014, 66(2):231-241. https://doi.org/10.1002/art.38291.

14. Mei Y, Pan F, Gao J, Ge R, Duan Z, Zeng Z, Liao F, Xia G, Wang S, Xu S et al: Increased serum IL-17 and IL-23 in the patient with ankylosing spondylitis. Clin Rheumatol 2011, 30(2):269-273. https://doi.org/10.1007/s10067-010-1647-4.

15. Wendling D, Cedoz JP, Racadot E, Dumoulin G: Serum IL-17, BMP-7, and bone turnover markers in patients with ankylosing spondylitis. Joint Bone Spine 2007, 74(3):304-305. https://doi.org/10.1016/j.jbspin.2006.11.005.

16. Adamopoulos IE, Bowman EP: Immune regulation of bone loss by Th17 cells. Arthritis Res Ther 2008, 10(5):225. https://doi.org/10.1186/ar2502.

17. Sato K, Suematsu A, Okamoto K, Yamaguchi A, Morishita Y, Kadono Y, Tanaka S, Kodama T, Akira S, Iwakura $Y$ et al: Th17 functions as an osteoclastogenic helper T cell subset that links T cell activation and bone destruction. $J$ Exp Med 2006, 203(12):2673-2682. https://doi.org/10.1084/jem.20061775.

18. Zhang JR, Pang DD, Tong Q, Liu X, Su DF, Dai SM: Different Modulatory Effects of IL-17, IL-22, and IL23 on Osteoblast Differentiation. Mediators Inflamm 2017, 2017:5950395. https://doi.org/10.1155/2017/5950395.

19. El-Zayadi AA, Jones EA, Churchman SM, Baboolal TG, Cuthbert RJ, El-Jawhari JJ, Badawy AM, Alase AA, El-Sherbiny YM, McGonagle D: Interleukin-22 drives the proliferation, migration and osteogenic differentiation of mesenchymal stem cells: a novel cytokine that could contribute to new bone formation in spondyloarthropathies. Rheumatology (Oxford) 2017, 56(3):488-493. https://doi.org/10.1093/rheumatology/kew384.

20. Baeten D, Baraliakos X, Braun J, Sieper J, Emery P, van der Heijde D, McInnes I, van Laar JM, Landewe $\mathrm{R}$, Wordsworth $\mathrm{P}$ et al: Anti-interleukin-17A monoclonal antibody secukinumab in treatment of ankylosing spondylitis: a randomised, double-blind, placebo-controlled trial. Lancet 2013, 382(9906):1705-1713. https://doi.org/10.1016/S0140-6736(13)61134-4.

21. Zhang L, Li YG, Li YH, Qi L, Liu XG, Yuan CZ, Hu NW, Ma DX, Li ZF, Yang Q et al: Increased frequencies of Th22 cells as well as Th17 cells in the peripheral blood of patients with ankylosing 
spondylitis and rheumatoid arthritis. PLoS One 2012, 7(4):e31000.

https://doi.org/10.1371/journal.pone.0031000.

22. Rusman T, van Vollenhoven RF, van der Horst-Bruinsma IE: Gender Differences in Axial Spondyloarthritis: Women Are Not So Lucky. Curr Rheumatol Rep 2018, 20(6):35. https://doi.org/10.1007/s11926-018-0744-2.

23. Gracey E, Yao Y, Green B, Qaiyum Z, Baglaenko Y, Lin A, Anton A, Ayearst R, Yip P, Inman RD: Sexual Dimorphism in the Th17 Signature of Ankylosing Spondylitis. Arthritis Rheumatol 2016, 68(3):679689. https://doi.org/10.1002/art.39464.

24. van der Linden S, Valkenburg HA, Cats A: Evaluation of diagnostic criteria for ankylosing spondylitis. A proposal for modification of the New York criteria. Arthritis Rheum 1984, 27(4):361-368. https://doi.org/10.1002/art.1780270401.

25. Sieper J, Rudwaleit M, Baraliakos X, Brandt J, Braun J, Burgos-Vargas R, Dougados M, Hermann KG, Landewe R, Maksymowych W et al: The Assessment of SpondyloArthritis international Society (ASAS) handbook: a guide to assess spondyloarthritis. Ann Rheum Dis 2009, 68 Suppl 2:ii1-44. https://doi.org/10.1136/ard.2008.104018.

26. Creemers MC, Franssen MJ, van't Hof MA, Gribnau FW, van de Putte LB, van Riel PL: Assessment of outcome in ankylosing spondylitis: an extended radiographic scoring system. Ann Rheum Dis 2005, 64(1):127-129. https://doi.org/10.1136/ard.2004.020503.

27. Regler för blodgivning [https://www.socialstyrelsen.se/stod-i-arbetet/organ-ochvavnadsdonation/blodgivning/]

28. Duhen T, Geiger R, Jarrossay D, Lanzavecchia A, Sallusto F: Production of interleukin 22 but not interleukin 17 by a subset of human skin-homing memory T cells. Nat Immuno/ 2009, 10(8):857-863. https://doi.org/10.1038/ni.1767.

29. Trifari S, Kaplan CD, Tran EH, Crellin NK, Spits H: Identification of a human helper T cell population that has abundant production of interleukin 22 and is distinct from $T(H)-17, T(H) 1$ and $T(H) 2$ cells. Nat Immuno/ 2009, 10(8):864-871. https://doi.org/10.1038/ni.1770.

30. Eyerich S, Eyerich K, Pennino D, Carbone T, Nasorri F, Pallotta S, Cianfarani F, Odorisio T, TraidlHoffmann C, Behrendt $\mathrm{H}$ et al: Th22 cells represent a distinct human T cell subset involved in epidermal immunity and remodeling. J Clin Invest 2009, 119(12):3573-3585.

https://doi.org/10.1172/JCl40202.

31. Res PC, Piskin G, de Boer OJ, van der Loos CM, Teeling P, Bos JD, Teunissen MB: Overrepresentation of IL-17A and IL-22 producing CD8 T cells in lesional skin suggests their involvement in the pathogenesis of psoriasis. PLoS One 2010, 5(11):e14108.

https://doi.org/10.1371/journal.pone.0014108.

32. Luan L, Ding Y, Han S, Zhang Z, Liu X: An increased proportion of circulating Th22 and Tc22 cells in psoriasis. Cell Immuno/ 2014, 290(2):196-200. https://doi.org/10.1016/j.cellimm.2014.06.007.

33. Pan HF, Li XP, Zheng SG, Ye DQ: Emerging role of interleukin-22 in autoimmune diseases. Cytokine Growth Factor Rev 2013, 24(1):51-57. https://doi.org/10.1016/j.cytogfr.2012.07.002. 
34. Ranganathan V, Gracey E, Brown MA, Inman RD, Haroon N: Pathogenesis of ankylosing spondylitis recent advances and future directions. Nat Rev Rheumatol 2017, 13(6):359-367. https://doi.org/10.1038/nrrheum.2017.56.

35. Ohnmacht C, Park JH, Cording S, Wing JB, Atarashi K, Obata Y, Gaboriau-Routhiau V, Marques R, Dulauroy S, Fedoseeva $\mathrm{M}$ et al: MUCOSAL IMMUNOLOGY. The microbiota regulates type 2 immunity through RORgammat(+) T cells. Science 2015, 349(6251):989-993. https://doi.org/10.1126/science.aac4263.

36. Sefik E, Geva-Zatorsky N, Oh S, Konnikova L, Zemmour D, McGuire AM, Burzyn D, Ortiz-Lopez A, Lobera $\mathrm{M}$, Yang $\mathrm{J}$ et al: MUCOSAL IMMUNOLOGY. Individual intestinal symbionts induce a distinct population of RORgamma(+) regulatory T cells. Science 2015, 349(6251):993-997. https://doi.org/10.1126/science.aaa9420.

37. Breban M, Tap J, Leboime A, Said-Nahal R, Langella P, Chiocchia G, Furet JP, Sokol H: Faecal microbiota study reveals specific dysbiosis in spondyloarthritis. Ann Rheum Dis 2017, 76(9):16141622. https://doi.org/10.1136/annrheumdis-2016-211064.

38. Klingberg E, Magnusson MK, Strid H, Deminger A, Stahl A, Sundin J, Simren M, Carlsten H, Ohman L, Forsblad-d'Elia $\mathrm{H}$ : A distinct gut microbiota composition in patients with ankylosing spondylitis is associated with increased levels of fecal calprotectin. Arthritis Res Ther 2019, 21(1):248. https://doi.org/10.1186/s13075-019-2018-4.

39. Ouyang W, Rutz S, Crellin NK, Valdez PA, Hymowitz SG: Regulation and functions of the IL-10 family of cytokines in inflammation and disease. Annu Rev Immunol 2011, 29:71-109. https://doi.org/10.1146/annurev-immunol-031210-101312.

40. Navid F, Colbert RA: Causes and consequences of endoplasmic reticulum stress in rheumatic disease. Nat Rev Rheumato/ 2017, 13(1):25-40. https://doi.org/10.1038/nrrheum.2016.192.

41. Do L, Granåsen G, Hellman U, Lejon K, Geijer M, X B, Witte T, Forsblad-d'Elia H: Anti-CD74 IgA autoantibodies in radiographic axial spondyloarthritis; a longitudinal Swedish study. Rheumatology (Oxford) 2020.

42. Baraliakos X, Baerlecken N, Witte T, Heldmann F, Braun J: High prevalence of anti-CD74 antibodies specific for the HLA class II-associated invariant chain peptide (CLIP) in patients with axial spondyloarthritis. Ann Rheum Dis 2014, 73(6):1079-1082. https://doi.org/10.1136/annrheumdis2012-202177.

43. Sogkas G, Klose K, Baerlecken N, Schweikhard E, Matthias T, Kniesch K, Schmidt RE, Witte T: CD74 is a T cell antigen in spondyloarthritis. Clin Exp Rheumatol 2020, 38(2):195-202.

44. Durcan L, Wilson F, Conway R, Cunnane G, O'Shea FD: Increased body mass index in ankylosing spondylitis is associated with greater burden of symptoms and poor perceptions of the benefits of exercise. J Rheumato/ 2012, 39(12):2310-2314. https://doi.org/10.3899/jrheum.120595.

45. Liew JW, Huang IJ, Louden DN, Singh N, Gensler LS: Association of body mass index on disease activity in axial spondyloarthritis: systematic review and meta-analysis. RMD Open 2020, 6(1). https://doi.org/10.1136/rmdopen-2020-001225. 


\section{Tables}

Table 1. Descriptive characteristics of 50 patients with ankylosing spondylitis, overall and stratified by sex. 


\begin{tabular}{|c|c|c|c|c|}
\hline & Total, $\mathrm{n}=50$ & $\begin{array}{l}\text { Men, } n=33 \\
(66.0 \%)\end{array}$ & $\begin{array}{l}\text { Women, n=17 } \\
\text { (34.0\%) }\end{array}$ & $\begin{array}{l}\mathrm{p}- \\
\text { value }\end{array}$ \\
\hline Age, years & $\begin{array}{l}54.5(45.5- \\
60.0)\end{array}$ & $53.0(45.5-60.0)$ & $56.0(44.5-60.5)$ & 0.6 \\
\hline $\mathrm{BMI}, \mathrm{kg} / \mathrm{m}^{2}$ & $\begin{array}{l}26.2(23.4- \\
31.1)\end{array}$ & $27.0(23.5-32.9)$ & $25.0(23.1-28.0)$ & 0.1 \\
\hline Ever smoker & $18(36)$ & $11(33.3)$ & $7(41.2)$ & 0.6 \\
\hline Symptom duration, years & $\begin{array}{l}31.0(21.0- \\
39.0)\end{array}$ & $32.0(21.5-39.5)$ & $30.0(20.5-38.0)$ & 0.7 \\
\hline HLA-B27 positive & $50(100)$ & & & \\
\hline $\mathrm{ESR}, \mathrm{mm} / \mathrm{h}$ & $8.0(3.8-15.2)$ & $6.0(4.9-14.5)$ & $10.0(3.0-18.5)$ & 0.5 \\
\hline hsCRP, mg/L & $2.1(0.8-5.2)$ & $1.8(0.8-6.0)$ & $2.3(0.7-3.8)$ & 0.8 \\
\hline $\begin{array}{l}\text { IL-22, } \mathrm{pg} / \mathrm{mL}, \mathrm{n}=49 \\
\text { (33 men and } 16 \text { women) }\end{array}$ & $\begin{array}{l}0.32(0.22- \\
0.50)\end{array}$ & $0.32(0.23-0.50)$ & $0.39(0.14-0.53)$ & 1.0 \\
\hline $\begin{array}{l}\text { IL- } 10, \mathrm{pg} / \mathrm{mL}, \mathrm{n}=49 \\
\text { (32 men and } 17 \text { women) }\end{array}$ & $\begin{array}{l}0.22(0.15- \\
0.30)\end{array}$ & $0.23(0.18-0.38)$ & $0.17(0.13-0.25)$ & 1.0 \\
\hline History of anterior uveitis & $26(52.0)$ & $17(51.5)$ & $9(52.9)$ & 0.9 \\
\hline $\begin{array}{l}\text { History of peripheral } \\
\text { arthritis }\end{array}$ & $30(60.0)$ & $22(66.7)$ & $8(47.0)$ & 0.2 \\
\hline ASDAS-CRP, score & $1.8(1.2-2.2)$ & $1.8(1.3-2.3)$ & $1.8(1.2-2.2)$ & 0.7 \\
\hline BASDAl, score & $3.4(2.2-5.5)$ & $3.1(2.0-5.5)$ & $4.0(3.2-5.4)$ & 0.2 \\
\hline BASFI, score & $2.2(0.9-3.9)$ & $2.1(0.8-4.0)$ & $2.5(1.0-4.0)$ & 0.7 \\
\hline BASMI, score & $3.2(2.4-5.2)$ & $4.0(2.5-5.5)$ & $3.0(2.4-4.1)$ & 0.2 \\
\hline NSAID, regular use & $30(60.0)$ & $19(57.6)$ & $11(64.7)$ & 0.6 \\
\hline csDMARD & $7(14.0)$ & $7(21.1)$ & $0(0)$ & 0.08 \\
\hline bDMARD & $12(24.0)$ & $10(30.3)$ & $2(11.8)$ & 0.2 \\
\hline $\begin{array}{l}\text { csDMARD and/or } \\
\text { bDMARD }\end{array}$ & $14(28.0)$ & $12(36.4)$ & $2(11.8)$ & 0.1 \\
\hline mSASSS, score & $4(0-31.0)$ & $18.0(2.5-42.0)$ & $1.0(0.0-5.5)$ & 0.006 \\
\hline$\geq 1$ Syndesmophyte & $23(46.0)$ & $19(57.6)$ & $4(23.5)$ & 0.02 \\
\hline
\end{tabular}

Values are median with interquartile range (IQR) or numbers of patients and percent (\%). BMI; body mass index, HLA-B27; human leukocyte antigen B27, ESR; erythrocyte sedimentation rate, hsCRP; high 
sensitivity C-reactive protein, BASDAl; Bath Ankylosing Disease Activity Index, ASDAS; Ankylosing Spondylitis Disease Activity Score, BASFl; Bath Ankylosing Spondylitis Functional Index, BASMl; Bath Ankylosing Spondylitis Metrology Index, NSAID; non-steroidal anti-inflammatory drug, csDMARD; conventional synthetic disease modifying anti-rheumatic drug, b; biologic, mSASSS; Modified Stoke Ankylosing Spondylitis Score.

Table 2. Descriptive characteristics of 17 women with ankylosing spondylitis, stratified by menopausal status. 


\begin{tabular}{|c|c|c|c|}
\hline Characteristics & $\begin{array}{l}\text { Postmenopasual women, } n=11 \\
(64.7 \%)\end{array}$ & $\begin{array}{l}\text { Premenopausal women, } n=6 \\
(35.3 \%)\end{array}$ & $\begin{array}{l}\mathrm{p}- \\
\text { value }\end{array}$ \\
\hline Age, years & $58.0(53.0-63.0)$ & $42,5(38.5-47.5)$ & $<0.001$ \\
\hline $\mathrm{BMI}, \mathrm{kg} / \mathrm{m}^{2}$ & $26.4(22.8-29.8)$ & $23.8(23.0-24.8)$ & 0.1 \\
\hline Ever smoker & $6(54.5)$ & $1(16.7)$ & 0.3 \\
\hline $\begin{array}{l}\text { Symptom duration, } \\
\text { years }\end{array}$ & $34.0(30.0-39.0)$ & $19.5(17.8-22.8)$ & $<0.001$ \\
\hline HLA-B27 positive & $11(100)$ & $6(100)$ & NA \\
\hline $\mathrm{ESR}, \mathrm{mm} / \mathrm{h}$ & $16.0(8.0-28.0)$ & $4.5(1.8-10.8)$ & 0.03 \\
\hline hsCRP, mg/L & $2.8(0.8-7.0$ & $2.2(0.6-2.9)$ & 0.4 \\
\hline $\mathrm{IL}-22, \mathrm{pg} / \mathrm{mL}, \mathrm{n}=16$ & $0.47(0.18-0.64)$ & $0.22(0.12-0.49)$ & 0.2 \\
\hline IL-10, pg/mL, n=17 & $0.23(0.14-0.26)$ & $0.15(0.11-0.19)$ & 0.1 \\
\hline $\begin{array}{l}\text { History of anterior } \\
\text { uveitis }\end{array}$ & $6(54.5)$ & $3(50.0)$ & 1.0 \\
\hline $\begin{array}{l}\text { History of peripheral } \\
\text { arthritis }\end{array}$ & $6(54.5)$ & $4(66.7)$ & 0.6 \\
\hline ASDAS-CRP, score & $1.9(1.5-2.2)$ & $1.1(0.9-1.9)$ & 0.05 \\
\hline BASDAI, score & $4.5(3.4-5.6)$ & $3.0(1.8-4.4)$ & 0.05 \\
\hline BASFI, score & $2.6(1.2-4.2)$ & $1.4(0.8-3.4)$ & 0.3 \\
\hline BASMI, score & $3.4(2.6-4.4)$ & $2.5(2.0-3.0)$ & 0.03 \\
\hline NSAID, regular use & $6(54.5)$ & $5(83.3)$ & 0.3 \\
\hline csDMARD & $0(0)$ & $0(0)$ & NA \\
\hline bDMARD & $0(0)$ & $2(33.3)$ & 0.1 \\
\hline $\begin{array}{l}\text { csDMARD and/or } \\
\text { bDMARD }\end{array}$ & $0(0)$ & $2(33.3)$ & 0.1 \\
\hline mSASSS, score & $3.0(0.0-8.0)$ & $0.0(0.0-1.2)$ & 0.05 \\
\hline$\geq 1$ Syndesmophyte & $4(36.4)$ & $0(0)$ & 0.2 \\
\hline
\end{tabular}

Values median with interquartile range (IQR) or numbers of patients and percent (\%). BMl; body mass index, HLA-B27; human leukocyte antigen B27, ESR; erythrocyte sedimentation rate, hsCRP; high sensitivity C-reactive protein, BASDAl; Bath Ankylosing Disease Activity Index, ASDAS; Ankylosing Spondylitis Disease Activity Score, BASFl; Bath Ankylosing Spondylitis Functional Index, BASMl; Bath Ankylosing Spondylitis Metrology Index, NSAID; non-steroidal anti-inflammatory drug, csDMARD; 
conventional synthetic disease modifying anti-rheumatic drug, b; biologic, mSASSS; Modified Stoke Ankylosing Spondylitis Score.

\section{Figures}

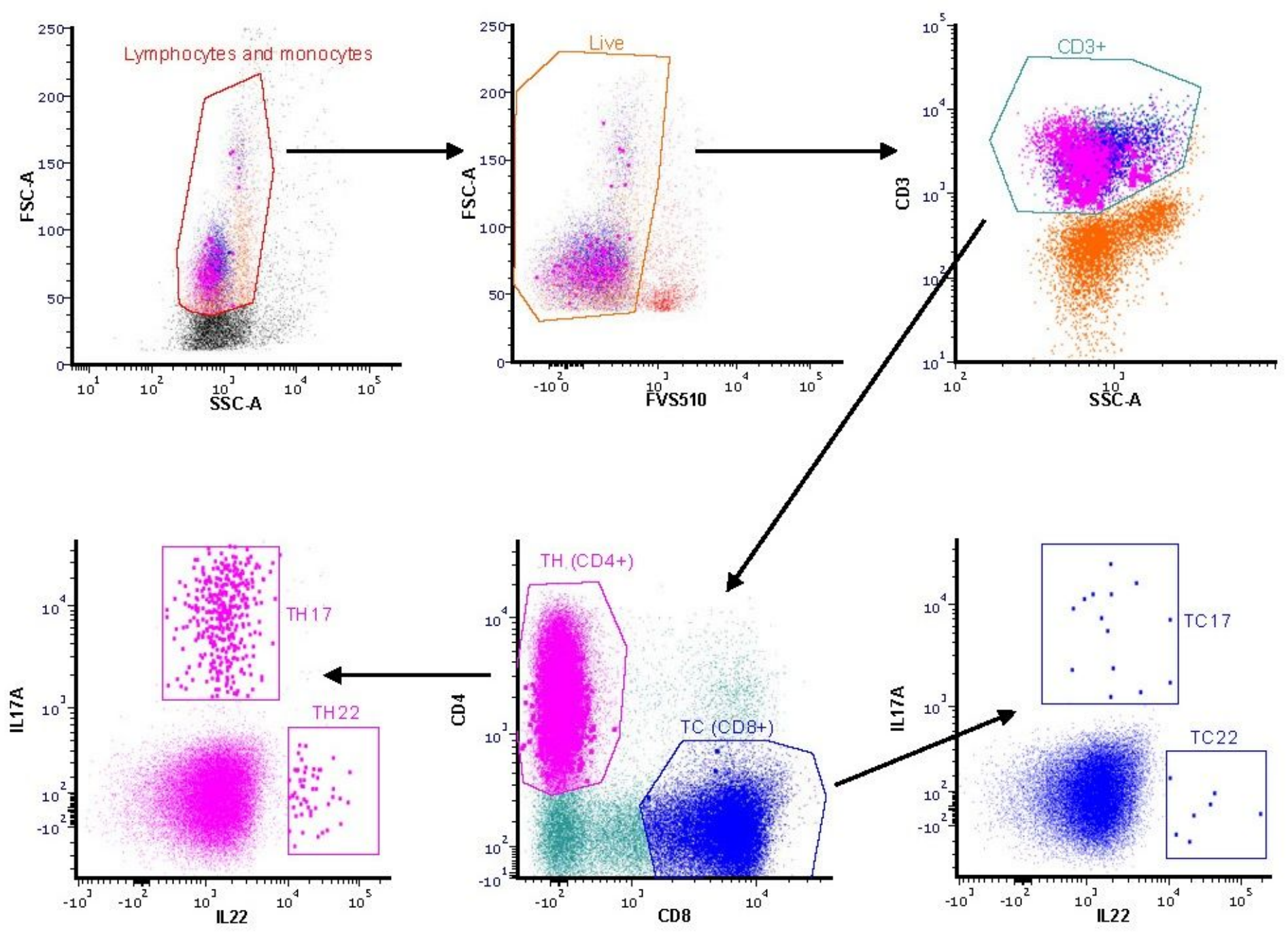

Figure 1

Gating strategy after flow cytometry analysis of antibody stained cells. 

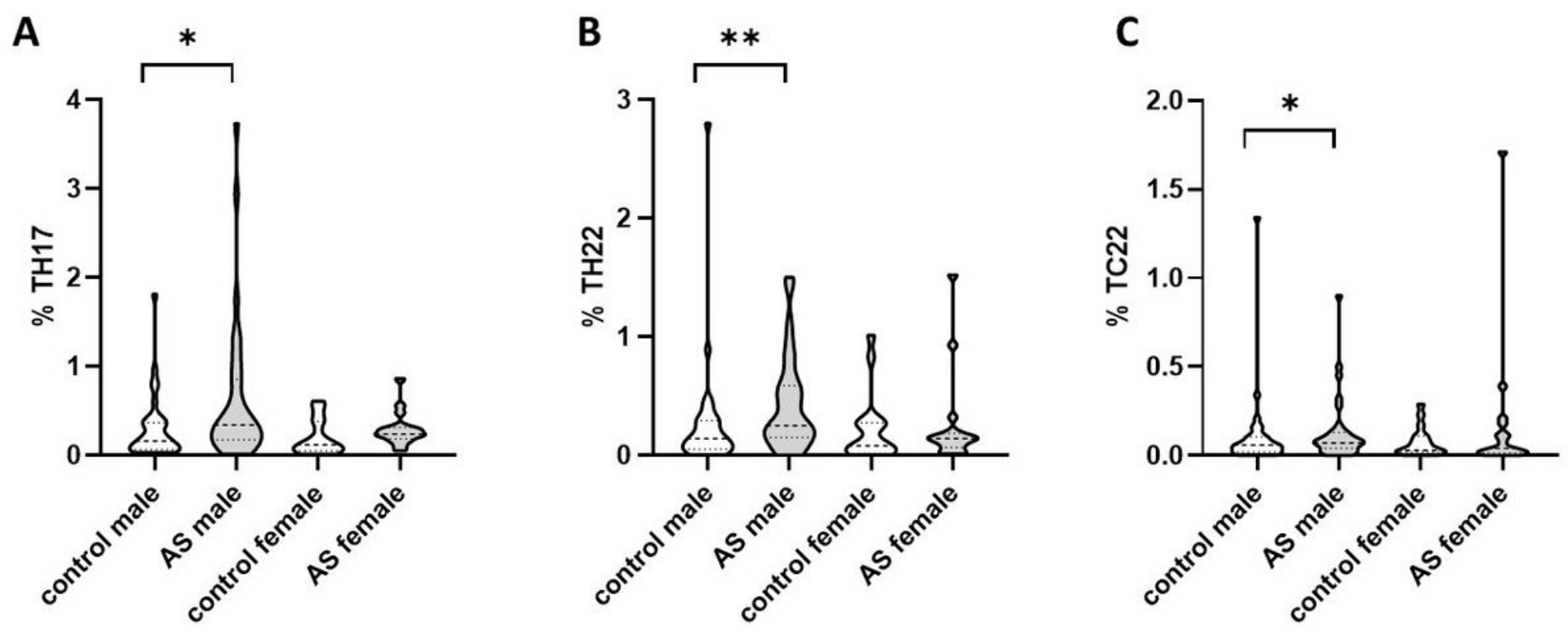

Figure 2

Gender wise comparison of (A) TH17, (B) TH22 and (C) TC22 proportions in peripheral blood leukocytes where * indicates $p=<0.05$ and $* *$ indicates $p=<0.005$. Dashed lines indicate median and interquartile ranges. 